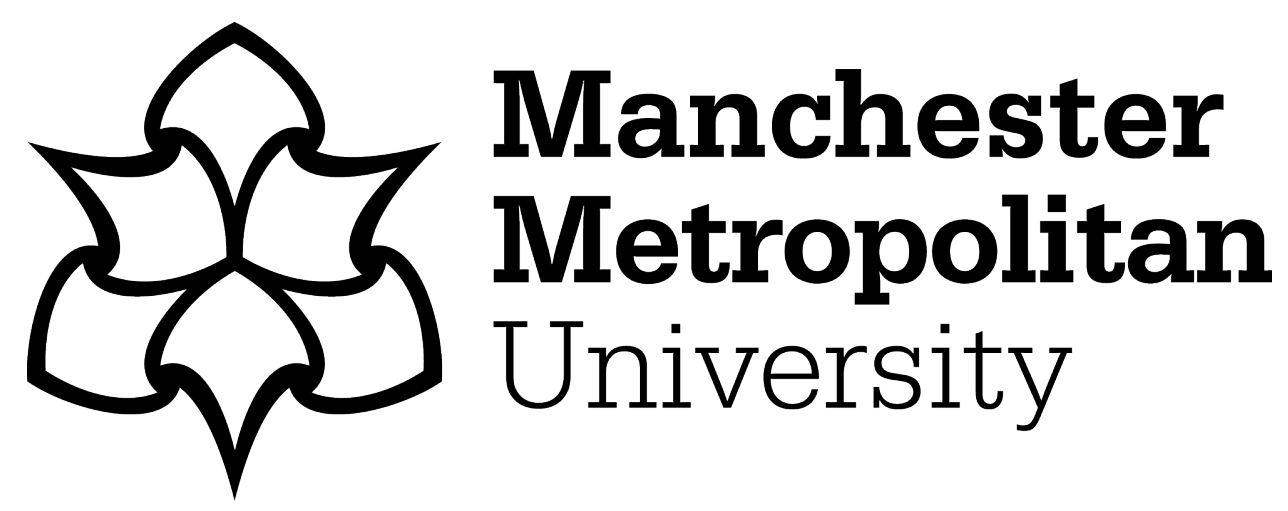

Stringfellow, Rachel, Keegan, Brendan ORCID logoORCID: https://orcid.org/0000-0002-8441-3763 and Rowley, Jenny ORCID logoORCID: https://orcid.org/0000-0003-3437-6914 (2019) The use of Facebook in the recruitment of foster carers: a dialogic analysis. Journal of Public Affairs, 19 (2). e1869. ISSN 1472-3891

Downloaded from: https://e-space.mmu.ac.uk/621549/

Publisher: Wiley

DOI: https://doi.org/10.1002/pa.1869

Please cite the published version 


\section{Journal of}

PUBLIC AFFAIRS

an international journal

\section{The use of Facebook in the recruitment of foster carers: a dialogic analysis}

\begin{tabular}{|r|l|}
\hline Journal: & Journal of Public Affairs \\
\hline Manuscript ID & JPA-18-105 \\
\hline Wiley - Manuscript type: & Academic Paper \\
\hline Keywords: & $\begin{array}{l}\text { social media, Facebook, fostering teams, local authorities, non-profit } \\
\text { organisations }\end{array}$ \\
\hline \multicolumn{2}{|c}{} \\
\hline
\end{tabular}

\section{SCHOLARONE \\ Manuscripts}




\title{
The use of Facebook in the recruitment of foster carers: a dialogic analysis
}

\begin{abstract}
Social media is becoming increasingly important for communication and community building, yet research on the use of social media by non-profit organisations is limited and largely restricted to content analysis of social media comments. This article contributes to addressing this research gap, through a survey-based study of the perspectives of key informants in UK Local Authority fostering teams on their use of social media. Specifically, it examines the extent to which the Facebook activity of local authority fostering teams is aligned with the principles of successful social media engagement, as represented by dialogic strategies and outcomes. A questionnaire on the use of Facebook was circulated to all local authority fostering teams in England. Findings suggest that whilst there is progress, many teams are at an early stage in their social media journey, and that there is considerable variation between agencies. The limited evidence of engagement in relation to dialogic principles suggests that there is some adoption of a strategic approach. In particular, of the three dialogic principles associated with successful online engagement, two (updating and community building) were applied by about half of local authority fostering teams and the third (engagement) by just over a quarter.
\end{abstract}

\section{Research paper}

Keywords: Social media; Facebook; Fostering teams; Local authorities; Non-profit organisations; dialogic strategies

\section{Introduction}

The purpose of this study is to understand how local authority (LA) fostering teams in England are using social media (SM) to support marketing and recruitment activity, with a specific focus on their use of Facebook. The need for LA fostering teams to recruit more of their own carers, and the potential for social media marketing to contribute to such recruitment, mean that this research area is of strategic importance to LAs. From an academic perspective, the research contributes to research into SM strategies, which suggests that many organisations, including LAs in the UK, are failing to exploit SM for online engagement and relationship building (Fitch, 2012; Kamel Boulos and Wheeler, 2007; Simpson, 2016).

This study uses Facebook as the SM platform for investigation because it is the most widely used in the UK today. According to the latest figures from Statista (2018), nearly 42 million UK citizens use Facebook. In addition, (Ellison and Hardey, 2014:30) suggest that Facebook offers LAs 'the clearest possibilities for sustained, detailed interaction between local people and 'their' local authority'.

The aim of this research is to examine the extent to which the Facebook activity of local authority fostering teams is aligned with the principles of successful social media engagement, as represented by dialogic strategies and outcomes. The specific objectives are to: 
- Identify and develop a theoretical framework for operationalising an engagement strategy using SM.

- Explore and critically evaluate the extent to which practitioners within the LA fostering sector are applying these principles in their use of Facebook.

\section{Context}

Foster carers play an essential role in the system for safeguarding children by providing a home for children who cannot safely remain with their birth families. Demand for foster carers is increasing in response to a steady rise in the number of children coming into care and a sharp decline in the number of adoption orders approved by the courts. At the end of March 2015, 52,050 children were with foster carers, equivalent to $75 \%$ of all looked after children in England (Department for Education, 2015).

Ensuring a sufficient supply of suitable foster carers to meet growing demand is critical. In England, this is delivered through a mixed economy of around 200 independent foster agencies (IFAs) (Ofsted, 2015a) and 147 LA services (Ofsted, 2015b). IFAs can be either non-profit or private agencies. The majority of IFAs are small and geographically focussed although there are larger, national agencies (including Action for Children and Barnardo's) and private companies (Corporate Watch, 2015). LAs have been unable to match growing demand with increased supply, giving rise to increasing reliance on IFAs (Bunker, 2014). However, the higher cost of commissioning IFAs relative to in-house carers (Ofsted, 2014), coupled with a $40 \%$ fall in LA funding and the 'flat cash' settlement for local government to 2019/20 announced by the Department for Communities and Local Government in December 2015 (Tole, 2015) make this dependence financially unsustainable. There is an urgent need for LAs to recruit more of their own carers, for which effective recruitment strategies are critical.

Increasingly, digital and social media are becoming an integral aspect of modern marketing communications campaigns (Keegan and Rowley, 2017). Many LAs and IFAs have established themselves on SM sites, particularly Facebook and Twitter, although some are also using Google+, You Tube, Pinterest, LinkedIn and various blogsites. One of the attractions of SM is its potential for engagement and relationship building. The decision to become a carer is a life changing one. Research on foster carer recruitment (Shuker, 2012; Sheldon, 2002) has highlighted the importance of personal connections in motivating recruitment. In addition, a sustained media presence, especially locally, may be key to reaching prospective carers (Sheldon, 2002), including the significant number of adults willing to consider fostering who have been neither reached nor targeted by existing marketing activities (Randle, Miller, Dolnicar and Ciarrochi, 2014; Scott and Duncan, 2013).

\section{Literature Review}

\subsection{Previous research}


There is a developing body of research that looks at the use of SM by non-profit organisations. However, this research has a focus on non-profit organisations in the US, with most of these studies examining the SM presence of the 'parent' organisation, rather than specific agencies or services with the organisation. For example, Nah and Saxton (2012), Lovejoy and Saxton (2012), Saxton and Waters (2014) and Cho, Schweickart, and Haase (2014) conduct content analyses relating to the SM presences of the 100 largest US non-profit organisations. Meanwhile Lovejoy and Saxton (2012) study SM in US advocacy organisations, and Lovejoy, Waters and Saxton (2012) examine how Twitter is used to engage the stakeholders of 73 non-profit organisations. Bortree and Saltzer (2009) undertake a content analysis of the Facebook profiles of fifty US environmental advocacy groups. Recently, Kanol and Nat (2017) examined causes and sectional groups' strategic use of Twitter from a European perspective, using an information-community-action scheme. Only Ellison and Hardy (2014) focus on SM in UK-based non-profits; they undertake a content analysis of the SM presence of all English LAs.

In addition, there is a significant methodological gap, with all of the studies on the SM presence of non-profit organisations being conducted using content analysis of SM, or web sites (e.g. Nah and Saxton, 2012). The focus of the content analysis varies both in terms of platform and the data extracted. With regard to platform, there is a predominance of studies into Twitter (Guo and Saxton, 2012; Lovejoy, Waters and Saxton, 2012; Lovejoy and Saxton, 2012; Waters and Jamal, 2011) or Twitter and other platforms (Nah and Saxton, 2012; Ellison and Hardey, 2014). This may be because Twitter is the most widely used platform due to the immediacy in information provision (Ellison and Hardey, 2014). On the other hand, there is some evidence that non-profits are using Twitter as a one-way communication channel (Ellison and Hardey, 2014; Lovejoy, Saxton and Waters, 2012; Waters and Jamal, 2011). Ellison and Hardey, who included Facebook and YouTube in their study, found that Twitter is the most widely used platform amongst English LAs, due to its immediacy in information provision. Consistent with this, Waters and Jamal (2011) found that Twitter was used for information provision, such as unidirectional updates and announcements and providing information and reports from outside organisations. Any two-way communication was more likely to be asymmetrical (e.g. participating in a survey poll or asking users to become involved in the organisation) than symmetrical.

Studies that examine Facebook and other platforms are therefore likely to offer greater insights into the dialogic potential of SM. In an early study of the Facebook presence of environmental advocacy groups, Bortree and Seltzer (2009) found that the groups used dialogic strategies to a limited extent, and found that conservation of members, generation of return visits and organisational engagement were significantly correlated with dialogic outcomes. On the other hand, they observed that 'most of the advocacy groups seem to adopt the position that the mere creation of interactive space via a social networking profile is sufficient for facilitating dialogue' (p.318). Cho et al. (2014) also found that for large nonprofit organisations, higher levels of engagement were associated with two-way symmetrical communications, as opposed to public information or two-way asymmetrical models of communication. Finally, Saxton and Walton (2014) examined the preference of individual stakeholders in relation to communication style in Facebook posts. On the basis of 
stakeholders' liking, commenting and sharing behaviours, they found that whilst individuals prefer dialogic, as well as certain forms of mobilizational messages, they are more likely to share one-way informational messages with their own networks. This suggests that there is scope for both informational and dialogic messages in a non-profit organisation's SM presences. However, notwithstanding the value of informational messages, this study focusses on dialogic strategies. Previous research on foster carers and the processes associated with cultivating their interest and commitment, suggest that dialogic strategies may be particularly important in this context (Sheldon, 2002; Randle et al., 2014; Scott and Duncan, 2013). Accordingly, this study seeks to develop and test an extended dialogic framework, and conduct a study of UK organisations, focussing on foster care agencies and their use of Facebook.

\subsection{Theoretical Foundations - Dialogic communication}

Saez Martin et al. (2015) suggests that dialogic 'theory is amongst the most commonly used to explain the interactive capability of the Internet as a channel for established social relationships' (p.425). Certainly, previous literature on online engagement and community building in the context of the use of SM in the non-profit sector has adopted the theoretical framework associated with dialogic communication (Cho et al. 2014; Lovejoy and Saxton, 2012; Kent, 2013). In their seminal work, Kent and Taylor (1998) set out five principles for using online media to develop 'dialogic communication': the dialogic loop, the usefulness of information, the ease of interface, the generation of return visits, and the conservation of visitors. These principles have been widely adopted. Some researchers use Kent's original framework (Rybalko and Seltzer, 2010; Waters, Canfield, Foster and Hard, 2011; Kim, Kim and Nam, 2013; Saez Martin et al., 2015), whilst others have developed the framework. Amongst these, Bortree and Seltzer (2009) added an additional engagement strategy, to include 'organisation comments in dialogic spaces', and proposed six dialogic outcomes, of which four measured use activity and organizational responsiveness, and two measured network extensiveness. Lovejoy and Saxton $(2012$; 2014) propose an additional dialogic strategy, community building and mobilisation.

This research also considers dialogic outcomes, used to measure the success of SM strategies. Boretree and Seltzer (2009) were concerned not just with dialogic strategies, but also with dialogic outcomes, and identified two measures of dialogic outcomes: user activity and responsiveness, and network extensiveness. These measures are consistent with the suggestions from many other authors regarding the centrality of relationship building in SM (Hoffman and Fodor, 2010; Whiting and Deshpande, 2014).

The dialogic strategies and outcomes proposed by the various authors were reviewed for their applicability for this study. Ultimately, the dialogic framework proposed for this research (Table 1) combines Kent and Taylor (1998)'s five principles, and Bortree and Seltzer's (2009) engagement principle and their dialogic outcomes. 


\section{Research methods}

\subsection{Participants}

Key informants in this study were identified as marketing staff within LAs in England with the remit for the recruitment of families to foster children. Most UK LAs have either a team, or marketing executive tasked with such recruitment and thus were deemed most suitable to offer insights into the use of SM. Specifically, potential respondents were initially identified from the Department for Education's list of the 149 LAs in England with children in foster care (Department for Education, 2015).

\subsection{Process}

Since 147 LAs fostering teams were operating in the UK (Ofsted, 2015b) at the time of the study, a qualitative study was deemed unsuitable for generating an overview of SM activities. A quantitative research design was chosen as the objectives of the research are concerned with measurement (Saunders, Lewis and Thornhill, 2015), specifically, to establish the prevalence of certain behaviours across a defined group. A survey was conducted using an online self-completed questionnaire, distributed using the Qualtrics survey software mailer. As email addresses were available for all teams, this approach was determined to be affordable, feasible and deliverable within the time frame of the proposed research project, and it eliminated any risk of interviewer bias (Bryman and Bell, 2010).

Despite the sensitive nature of fostering, a survey of LA recruitment teams did not present any potential harm to participants, or violation of their dignity or privacy of foster families. The email communication inviting participants to engage in the research ensured its nature and purpose were clear and identified the credentials of the researchers. It also assured participants that all data would be collected anonymously and stored safely.

The initial round of questionnaires was distributed to generic addresses (e.g. fostering@...gov.uk) taken from the list maintained by the Adoption and Fostering Academy (Coram/BAFF, 2015). The initial response was 21 (14.1\%). One factor contributing to this low response was the high number of incorrect email addresses, due to the out-of-date details on websites. To increase the response rate, a more targeted approach was adopted. Nonresponding agencies were contacted by phone to locate a named individual with responsibility for marketing and the recruitment of foster carers. An email was sent directly to this person from the researcher's LA email account, and, wherever possible, contact was made over the phone by the researcher. This more targeted approach delivered a further 39 responses. Thus, the overall response rate was $40.3 \%(60 / 149)$.

\subsection{Measures}

Table 1 summarises the SM practices identified in the literature, maps them to a revised dialogic framework, and provides validation for the questions that are included in the questionnaire. In addition, data was collected on three attribute variables: the number of 
children in foster care with the agency; access to professional support; and, the use of Facebook Insights to monitor user activity.

\section{Findings}

\section{Insert Table 1 Here}

\subsection{Attribute variables}

There are three attribute variables, relating respectively to the number of children in fostering care, access to professional support, and the use of Facebook Insights. Figure 1 shows that the sample included agencies with varying levels on engagement in foster care. Table 2 shows that the majority of respondents with access to in-house professional marketing and communications support are using Facebook Insights to monitor online activity.

\section{Insert Figure 1 Here}

Insert Table 2 Here

\subsection{Behavioural variables}

\subsubsection{Dialogic strategies}

Table 3 summarises the data for the questions relating to dialogic strategies adopted by the agencies. In relation to Principle 1, engagement, it was noted that there is some inconsistency between the frequency of posting with 16 agencies indicating only ' 2 to 3 times a week' and only 21 respondents inviting any user participation. On the other hand, for Principle 2, organisational responsiveness, 27 'always' replied, whereas 6 responded only 'sometimes'. However, that agencies responded to all visitors' posts: 21 would do so 'on the same day' whereas 12 would take longer than this. On Principle 3, transparency, agencies do offer communication links, such as contact phone numbers, and websites links, but fewer offer details about the organisation, such as where it is located or its mission statement. For Principle 4, updating and links to related content, there is an indication that there is a strong preference for providing access to information via links posted to the Timeline, over the use of tabs on the page itself. 28 agencies confirmed they didn't use the Notes tab on their Facebook pages. Similarly, for the Events tab, 14 respondents reported that they didn't use it extensively, although the same proportion did claim to use it whenever they had a new event. By contrast, 18 agencies claimed to post to information or articles of interest on their 
Timeline at least once a week, with half of these posting several times a week and the other half, once a week. On Principle 5, visual appeal, the responses indicate a clear preference for photos over videos with 14 respondents posting photos at least once a week, 8 posting several times a week. Finally, for Principle 6, community building and mobilisation, responses suggest that that fostering teams' 'community building' preferences are revealed more strongly in commenting on issues perceived to be of mutual interest than in thanking their community. Only 10 reported doing this 'regularly' compared to 14 responses for 'occasionally'. A similarly low proportion of respondents posted comments about issues of mutual interest either weekly or several times a week, with 14 posting 'at least once a week', and 10 posting 'at least once a month'. As regards actively inviting participation, promoting events is clearly the preferred means with all respondents responding positively. By contrast, none asked for donations or sold merchandise, activities that are possibly not appropriate to the activity of recruiting foster carers.

\section{Insert Table 3 Here}

\subsubsection{Dialogic outcomes}

Table 4 summarises the data for the questions relating to dialogic outcomes experienced by the agencies. Questions on the use of the Reviews tab and the frequency of visitor posts are used to measure user engagement. The Reviews tab appears to play a limited role in Facebook activity. 21 did not use a Reviews tab and of those who did have a Reviews tab, only one respondent reported that they received reviews regularly. Combined with the findings reported for Principle 4, this suggests that as a group, fostering teams make limited use of the tabs available on Facebook. In contrast, in respect of visitor posts, although 6 respondents claimed to post 'less frequently than 2-3 times a month', 10 respondents report that posts are made by visitors at least once a week, and of these 7 agencies reported daily posts.

\section{Insert Table 4 Here}

For 'network extensiveness', there is evidence of some activity, but at a relatively low level (Table 5). The most consistent figure for Likes is between 0-499, suggesting low levels of user activity. Furthermore, the 'number of Likes per month' confirm this, with the majority of respondents (11) indicating that they received between 10 to 24 Likes over the period of the previous month.

\section{Insert Table 5 Here}

\subsection{Context}


Thematic analysis of the open question comments provided some insights on the context for the operation of Facebook presences by the fostering teams. Since the extent and number of these text comments was limited, the researchers were able to undertake a quick review of the emergent themes. These are: links between fostering agency and other Facebook presences; and, level of experience with the use of Facebook.

Four respondents explained that their Facebook presence was on the LA or corporate Facebook page; generally, they viewed this as inhibiting their development of an effective dialogue with potential carers through Facebook:

I believe that we should have access to a dedicated service to enhance our profile as a service. We are competing in a very difficult market.

In Xshire, the fostering service uses the X County Council general Facebook page instead of having its own dedicated fostering Facebook page.

A fifth described a joint Facebook fostering account with five other London LAs.

We have a joint Facebook account with five more north London LAs. We find that a

joint account is a great platform to publish varied content and share a wider variety

of news items.

Others suggested that they were in the early stages of their use of Facebook, and were keen to learn more:

We only launched our Facebook page at the start of the year so are still experimenting with this. We would be very interested in results.

On the other hand, one more experienced user reported on the value of having an active Facebook presence.

Around 20\% of enquiries now come from Facebook, either through adverts, posts that have been shared, or people seeking out our page directly.

\section{Discussion and Conclusion}

This study contributes to the limited body of knowledge on SM strategy in the non-profit sector by offering insights into the way in which foster carers are using Facebook. In an increasingly competitive marketplace for the recruitment of carers, fostering agencies are taking an increasing interest in the potential of SM. However, disappointingly, this study shows that many fostering agencies, in common with other public-sector organisations (Fitch 2012; Simpson, 2016) have a long way to go before they fully capitalise on the potential of SM for online engagement and relationship building. First, some have only very recently started working with Facebook. Secondly, several express concerns regarding the constraints imposed by having their Facebook presence coupled with that of their LA. Indeed, the relatively low rate of response in this survey may be a further indicator that many LA's either do not use SM or are not using them effectively.

The main focus of this study is the extent to which fostering teams engage in dialogic (or two-way) communication through their Facebook presence, and whether as a result they 
achieve the dialogic outcomes. This research suggests that the extended and adapted dialogic framework proposed at the beginning of this article is a good reflection of the range of activities in which the fostering agencies engage with respect to SM. However, their engagement with and level of posting to their SM sites is at a relatively low level in terms of frequency of activity in respect of some of the principles, and there is considerable variability between agencies. Broadly, agencies post to their timeline between two to three times a week, and sometime invite their community to participate in polls, offer views or ideas or enter competitions (principle 1). They are very responsive to visitors' posts, with most always responding, and doing so within the next couple of days (principle 2). On transparency, contact numbers, e-mail addresses, website links, and organisational descriptions are frequently provided (principle 3). On the other hand, agencies are a little tardy with their updating, with such postings often being triggered by the need to promote an event (principle 4). Most organisations post photos at least once a week, and videos occasionally (principle 5). Most post messages to thank their community occasionally, and post comments about current issues or events once a month or more frequently (principle 6).

The other question is whether the activities associated with maintaining a Facebook presence achieve dialogic outcomes. Visitors do post on the fostering agency's Facebook page, but the degree of frequency varies between agencies. On the other hand, of those who have reviews tabs, only a few receive review posts (outcome 1). In terms of likes, most agencies have between 0-499 likes, but some do have many more (e.g. over 2000), and they are receiving some new likes (typically up to 49) each month (outcome 2). Overall, then agencies are achieving some response from their Facebook visitors, although, in the absence of any benchmarks for this sector, it is difficult to evaluate outcomes.

From the theoretical perspective, this research explores the use of a revised dialogic framework that incorporates Kent and Taylor (1998)'s five principles, with Bortree and Seltzer's (2009) engagement principle and dialogic outcomes, and demonstrates the value of such a framework as a means of evaluating key stakeholders' perspectives on their organisation's social media presence. However, whilst it is recognised that dialogic communication is important, it is possible that social media is also an important channel for one-way communication; this is not explored in this study.

The research also adds to the body of knowledge on the use of SM by non-profit organisations. It chooses a context, local authority fostering teams, in which dialogic communication has been found not be particularly relevant (Sheldon, 2002; Randle et al., 2014). Furthermore, in contrast to the majority of other studies in the field which are conducted in the US and use content analysis of social media (e.g. Nah and Saxton, 2012; Cho, Schweickart and Haase, 2014), this study is based on UK-based foster agencies, and uses a questionnaire-based approach. It thereby gathers the perspectives of those responsible for social media presences, and engages them in reflection on their use and potential future use of social media.

\section{Recommendations for practice and further research}


One of the limitations of this study is its sample size. This is one of the hazards of undertaking research in which there is a limited number of qualified key informants, all of whom are busy. Hence, the recommendations in this section are tentative.

This study suggests that there is an awareness amongst fostering agencies regarding the adoption of dialogic communication, but the variability of practice suggests that there is considerable scope for the identification and sharing of best practice. One consortium in London is adopting a collaborative approach. Another key issue for many agencies is that their Facebook presence is 'entangled' with that of their LA; this is a challenge that faces many LA agencies, such as libraries and museums. It would be beneficial for LAs to undertake a review of their SM activities and develop an SM strategy that accommodates the very different requirements of the various services under their wing. On addition, LA fostering agencies would benefit from undertaking a review of their marketing strategies, and some appropriate exchange of best practice.

There is also significant scope for further research into the use of SM, in general, but Facebook more specifically, in non-profit organisations. As discussed earlier, much of the previous work in this field focusses on Twitter and has been conducted in the US. This study is one of the first to conduct a survey that engages those responsible for social media. Further surveys exploring other aspects of social media strategies and use would offer additional insights, as would further qualitative studies, which could be expected to surface some of the challenges and benefits associated with the use of social media for marketing and community-building in non-profit and public sector organisations. Finally, another strand of research might explore the views of potential foster carers on their use of social media in support of their role.

Finally, whilst this study has examined dialogic outcomes, there is scope for further development of pragmatic approaches to the evaluation of the contribution of SM presences in non-profit organisations.

\section{References}

Barrance, T. (2015). Framing Gov2.0: A Q-Methodological study of practitioners' and local politicians' opinions. Local Government Studies, 3930 (September), 1-18.

Bonson, E., Royo, S. and Ratkai, M. (2015) Citizens' engagement on local governments' Facebook sites. An empirical analysis: The impact of different media and content types in Western Europe. Government Information Quarterly, 32(1), 52-62.

Bortree, D.S. and Seltzer, T. (2009). Dialogic strategies and outcomes: An analysis of environmental advocacy groups' Facebook profiles. Public Relations Review, 35(3), $317-$ 319.

Bryman, A. and Bell, E. (2010). Business Research Methods. 4th ed., New York, USA: Oxford University Press. 
Bunker, P. (2014). Looked After Children Summit - Data Report. Unpublished paper presented to the North West Association of Directors of Children's Services, October 2014

Cho, M., Schweickart, T. and Haase, A. (2014). Public engagement with non-profit organizations on Facebook. Public Relations Review, 40(3), 565-567.

Coram/BAAF (2015). Fostering Agency Finder. [Online] [Accessed 20 ${ }^{\text {th }}$ July 2018]. http://www.baaf.org.uk/agencies?page $=3 \&$ area_search $=\&$ title $=\&$ keys $=\&$ activity[0] $=1065$

Corporate Watch (2015). The Foster Care Business. [Online] [Accessed 20 ${ }^{\text {th }}$ July 2018] https://corporatewatch.org/news/2015/dec/15/foster-care-business

Department for Education (2015). Children looked after in England (including adoption and care leavers) year ending 31 March 2015. Department for Education. [Online] [Accessed $20^{\text {th }}$ July 2018]

https://www.gov.uk/government/uploads/system/uploads/attachment_data/file/464756/SFR34 _2015_Text.pdf

Ellison, N. and Hardey, M. (2014). Social media and local government: Citizenship, consumption and democracy. Local Government Studies, 40(1), 21-40.

Fitch, D. (2012). Youth in foster care and social media: A framework for developing privacy guidelines. Journal of Technology in Human Services, 30(2), 94-108.

Guo, C. and Saxton, G.D. (2012). Tweeting social change: how social media are changing nonprofit advocacy. Nonprofit and Voluntary Sector Quarterly, 43 (1), 57-79.

Hoffman, D. and Fodor, M. (2010). Can you measure the ROI of your social media marketing? MIT Sloan Management Review, October, 41-49.

Kamel Boulos, M. N., and Wheeler, S. (2007). The emerging Web 2.0 social software: an enabling suite of sociable technologies in health and health care education. Health Information \& Libraries Journal, 24(1), 2-23.

Kanol, D. and Nat, M. (2017). Interest groups and social media: An examination of cause and sectional groups' social media strategies in the EU. Journal of Public Affairs, 17(3), 1-6.

Keegan, B. J., and Rowley, J. (2017). Evaluation and decision making in social media marketing. Management Decision, 55(1), 15-31.

Kent, M.L. (2013) Using social media dialogically: public relations in the reviving democracy. Public Relations Review, 39(4), 337-345.

Kent, M.L. and Taylor, M. (1998). Building dialogic relationships through the World Wide Web. Public Relations Review, 24(3), 321-322.

Kim, D., Kim, J. and Nam, Y. (2013). How does industry use social networking sites? An analysis of corporate dialogic uses of Facebook, Twitter, YouTube, and LinkedIn by industry type. Quality and Quantity, 48, 2605-2614. 
Lovejoy, K. and Saxton, G.D. (2012). Information, community, and action: How non-profit organizations use social media. Journal of Computer-Mediated Communication, 17(3), 337353.

Lovejoy, K., Waters, R.D. and Saxton, G.D. (2012). Engaging stakeholders through Twitter: How non-profit organizations are getting more out of 140 characters or less. Public Relations Review, 38(2), 313-318.

Nah, S. and Saxton, G.D. (2013). Modelling the adoption and use of social media by nonprofit organisations. New Media \& Society, 15 (2), 294-313.

Ofsted (2014). Removing barriers to foster carer recruitment: Kirklees Council. [Online] [Accessed 20 July 2018] https://www.gov.uk/government/publications/removing-barriersto-foster-care-recruitment

Ofsted (2015a). FOI: Social care dataset as at 20 March 2015. Ofsted. [Online] [Accessed $20^{\text {th }}$ July 2018] https://www.gov.uk/government/statistical-data-sets/foi-social-care-datasetas-at-20-march-2015

Ofsted (2015b). Fostering in England, 1 April 2013 to 31 March 2014. Ofsted. [Online] [Accessed $20^{\text {th }}$ July 2018] https://www.gov.uk/government/statistics/fostering-in-england-1april-2013-to-31-march-2014

Randle, M., Miller, L., Dolnicar, S. and Ciarrochi, J. (2014). The science of attracting foster carers. Child and Family Social Work, 19(1), 65-75.

Rybalko, S. and Seltzer, T. (2010). Dialogic communication in 140 characters or less: How Fortune 500 companies engage stakeholders using Twitter. Public Relations Review, 36 (4), 336-341.

Saez Martin, A., de Rosario, A.H., and Caba Perez, M. (2015). Using Twitter for dialogic communication local government strategies in the European Union, Journal of Government Studies, 41 (3), 421-444.

Saunders, M., Lewis, P. and Thornhill, A. (2015). Research Methods for Business Students. $7^{\text {th }}$ Edition. Harlow, England: Pearson.

Saxton, G.D. and Waters, R.D. (2014). What do stakeholders like on Facebook? Examining public reactions to non-profit organizations' informational, promotional, and communitybuilding messages. Journal of Public Relations Research, 26(3), 280-299.

Scott, A. and Duncan, C. (2013). Understanding attitudes, motivations and barriers to adoption and fostering: A marketing proposal for the Department for Education. Department for Education. [Online] [Accessed $20^{\text {th }}$ July 2018]

http://media.education.gov.uk/assets/files/pdf/u/dfe adoption and fostering marketing proposal.pdf

Sheldon, J. (2002). 'A word in your ear': A study of foster carers' attitudes to recommending fostering to others, Child Care in Practice, 8(1), 19-34. 
Shuker, L. (2012). The Recruitment of Foster Carers: Key Messages from The Literature. University of Bedfordshire. [Online] [Accessed 20 th July 2018] https://www.beds.ac.uk/_data/assets/pdf_file/0004/203593/The-Recruitment-of-FosterCarers-Dr-Lucie-Shuker.pdf

Simpson, J. E. (2016). A divergence of opinion: How those involved in child and family social work are responding to the challenges of the Internet and social media. Child \& Family Social Work, 21(1), 94-102.

Sisco, H. and McCorkindale, T. (2013). Communicating "pink": an analysis of the communication strategies, transparency, and credibility of breast cancer social media sites. International Journal of Nonprofit and Voluntary Sector Marketing, 18(4), 287-301.

Statista, (2018). Social media usage in the United Kingdom (UK) - Statistics \& Facts [Online] [Accessed 20 ${ }^{\text {th }}$ July 2018] Retrieved from:

https://www.statista.com/topics/3236/social-media-usage-in-the-uk/

Tole, A. (2015). Briefing: Provisional Local Government Finance Settlement 2016-2017 and an offer to councils for future years. Local Government Association. [Online] http://www.local.gov.uk/documents/10180/11309/LGA+On+the+Day+Briefing++Provisiona 1+Local+Government+Finance+Settlement++17+December+2015/6641bf96-a677-4870$8887-5$ ec0dc551a56[Accessed $20^{\text {th }}$ July 2018]

Waters, R., Canfield, R., Foster, J. and Hardy, E. (2011). Applying the dialogic theory to social networking sites: Examining how university health centres convey health messages on Facebook. Journal of Social Marketing, 1(3), 211-227

Waters, R.D. and Jamal, J.Y. (2011). Tweet, tweet, tweet: A content analysis of non-profit organizations' Twitter updates. Public Relations Review, 37(3), 321-324.

Whiting, A. and Deshpande, A. (2014). Social media marketing: A myth or a necessity Journal of Applied Business and Economics, 16(5), 74-81. 
Table 1 Dialogic Framework and Questionnaire Design

\begin{tabular}{|c|c|c|}
\hline Dialogic Principles & Question & Corresponding/Informative Works \\
\hline \multirow[t]{2}{*}{$\begin{array}{l}\text { Engagement organisation } \\
\text { commenting posting in } \\
\text { dialogic spaces }\end{array}$} & How frequently do you post to your Timeline? & $\begin{array}{l}\text { Bortree and Seltzer, 2009; Rybalko and } \\
\text { Seltzer, 2010; Sisco and McCorkindale, } \\
\text { 2013; }\end{array}$ \\
\hline & $\begin{array}{l}\text { Do you invite your Facebook community to participate in polls, offer views or ideas or } \\
\text { enter competitions? }\end{array}$ & Waters et al., 2011 \\
\hline \multirow{2}{*}{$\begin{array}{l}\text { 2. Organisational } \\
\text { responsiveness }\end{array}$} & Do you respond to visitors' posts? & \multirow{2}{*}{$\begin{array}{l}\text { Bortree and Seltzer, 2009; Waters et al., } \\
\text { 2011; }\end{array}$} \\
\hline & How quickly do you respond to visitors' posts? & \\
\hline $\begin{array}{l}\text { 3. Transparency and } \\
\text { provision of information } \\
\text { about the organisation }\end{array}$ & $\begin{array}{l}\text { Does your 'About' page include (i) a contact phone number (ii) an email address (iii) a } \\
\text { postal address (iv) a website link (v) a mission statement (vi) a description of what your } \\
\text { organisation does? }\end{array}$ & $\begin{array}{l}\text { Waters et al., 2011; Kim et al., 2013; Saez } \\
\text { Martin et al., } 2015\end{array}$ \\
\hline \multirow{3}{*}{$\begin{array}{l}\text { 4. Updating and providing } \\
\text { links to related content }\end{array}$} & Do you have an 'Events' tab on your Facebook page? & Waters, 2011; Rybalko and Seltzer, 2010. \\
\hline & Do you have a 'Notes' tab on your Facebook page? & \multirow[t]{2}{*}{ Sisco and McCorkindale, 2013; } \\
\hline & $\begin{array}{l}\text { Do you post links in your Timeline to information or articles of interest to your } \\
\text { Facebook community? }\end{array}$ & \\
\hline 5. Visual appeal & Do you post photos, or videos on your Facebook page? & Waters et al. ,2011; Bonson et al., 2015 \\
\hline \multirow[t]{3}{*}{$\begin{array}{l}\text { 6. Community building and } \\
\text { mobilisation }\end{array}$} & $\begin{array}{l}\text { Do you post messages to thank your community and/or show your appreciation for the } \\
\text { support they provide to your organisation and to foster children? }\end{array}$ & \multirow[t]{2}{*}{ Rybalko and Seltzer, 2010} \\
\hline & $\begin{array}{l}\text { Do you post comments about current issues or events that you think will interest your } \\
\text { Facebook community? }\end{array}$ & \\
\hline & $\begin{array}{l}\text { Do you use posts or tabs on your Facebook page to (a) promote events (b) ask for } \\
\text { donations (c) seek volunteers (d) sell merchandise? }\end{array}$ & $\begin{array}{l}\text { Taylor et al., 2001; Lovejoy and Saxton, } \\
\text { 2012; Saxton and Waters, } 2014\end{array}$ \\
\hline \multirow{2}{*}{$\begin{array}{l}\text { 7. User activity and } \\
\text { responsiveness }\end{array}$} & How frequently do visitors post to your Timeline? & \multirow{4}{*}{$\begin{array}{l}\text { Boretree and Seltzer, 2009; Hoffman and } \\
\text { Fodor, 2010; Whiting and Dashpande, } 2014\end{array}$} \\
\hline & Do you have a Reviews tab on your profile? & \\
\hline \multirow[t]{2}{*}{ 8. Network extensiveness } & How many Likes do you currently have on your Facebook page? & \\
\hline & How many new Likes did you receive last month? & \\
\hline
\end{tabular}


Table 3 - Application of Dialogic Principles

\begin{tabular}{|c|c|c|c|c|c|}
\hline Principle 1 & Engagement & & 8 & & \\
\hline How freque & atly do you po. & to your $T i$ & ine? & & \\
\hline $\begin{array}{l}\text { Daily of } \\
\text { more } \\
\text { frequently }\end{array}$ & $\begin{array}{l}\text { Two to three } \\
\text { times a week }\end{array}$ & One a week & $\begin{array}{l}2-3 \text { times a } \\
\text { month }\end{array}$ & $\begin{array}{l}\text { Less } \\
\text { frequently }\end{array}$ & Never \\
\hline 5 & 16 & 8 & 5 & 3 & 0 \\
\hline
\end{tabular}

Do you invite your Facebook community to participate in polls, offer views or ideas or enter competitions?

\begin{tabular}{|c|c|c|c|c|c|}
\hline $\begin{array}{l}\text { Yes } \\
\text { regularly }\end{array}$ & $\begin{array}{l}\text { Yes. } \\
\text { sometimes }\end{array}$ & No & & 80 & \\
\hline 5 & 11 & 21 & & & \\
\hline \multicolumn{6}{|c|}{ Principle 2-Organisational responsiveness } \\
\hline \multicolumn{6}{|c|}{ Do you respond to visitors' posts? } \\
\hline Always & Sometimes & Rarely & Never & $\begin{array}{l}\text { We do not } \\
\text { receive any } \\
\text { visitors' } \\
\text { posts }\end{array}$ & \\
\hline 27 & 6 & 0 & 0 & 2 & \\
\hline \multicolumn{6}{|c|}{ How quickly do you respond to visitors' posts? } \\
\hline $\begin{array}{l}\text { The same } \\
\text { day }\end{array}$ & $\begin{array}{l}\text { Within a } \\
\text { couple of days }\end{array}$ & $\begin{array}{l}\text { Within the } \\
\text { week }\end{array}$ & $\begin{array}{l}\text { It varies - } \\
\text { when we have } \\
\text { time }\end{array}$ & $\begin{array}{l}\text { We don't } \\
\text { respond }\end{array}$ & $\begin{array}{lr}\text { We } & \text { don't } \\
\text { receive } & \text { any } \\
\text { posts } & \\
\end{array}$ \\
\hline 21 & 12 & 0 & 0 & 0 & 2 \\
\hline
\end{tabular}




\begin{tabular}{|c|c|c|c|c|c|c|}
\hline \multicolumn{7}{|c|}{ Features of respondents' About pages } \\
\hline $\begin{array}{l}\text { Contact } \\
\text { phone } \\
\text { number }\end{array}$ & e-mail address & Postal address & Website link & $\begin{array}{l}\text { Mission } \\
\text { statement }\end{array}$ & $\begin{array}{l}\text { Description of } \\
\text { what the } \\
\text { organisation } \\
\text { does }\end{array}$ & \\
\hline 31 & 31 & 17 & 33 & 8 & 28 & \\
\hline \multicolumn{7}{|c|}{ Principle 4 - Updating and providing links to related content } \\
\hline $\begin{array}{l}\text { Yes and we } \\
\text { update it } \\
\text { weekly }\end{array}$ & $\begin{array}{lr}\text { Yes, and } & \text { we } \\
\text { update } & \text { it } \\
\text { monthly } & \end{array}$ & $\begin{array}{l}\text { Yes, and we } \\
\text { update it } \\
\text { whenever we } \\
\text { have a new } \\
\text { event }\end{array}$ & $\begin{array}{l}\text { No. we don't } \\
\text { have an Events } \\
\text { tab }\end{array}$ & & & \\
\hline 3 & 3 & 14 & 14 & & & \\
\hline \multicolumn{7}{|c|}{ Do you have a Notes tab on your Facebook page? } \\
\hline $\begin{array}{l}\text { Yes, and we } \\
\text { add to it } \\
\text { weekly }\end{array}$ & $\begin{array}{l}\text { Yes, and we } \\
\text { add to it at } \\
\text { least monthly }\end{array}$ & $\begin{array}{l}\text { Yes, and we } \\
\text { add to it } \\
\text { occasionally }\end{array}$ & $\begin{array}{l}\text { Yes, but we } \\
\text { don't use it }\end{array}$ & No & & \\
\hline 0 & 0 & 3 & 3 & 28 & & \\
\hline \multicolumn{7}{|c|}{$\begin{array}{l}\text { Do you post links in your Timeline to information or articles of interest to your Facebook } \\
\text { community }\end{array}$} \\
\hline $\begin{array}{l}\text { Yes, several } \\
\text { times a week }\end{array}$ & $\begin{array}{l}\text { Yes, at least } \\
\text { once a week }\end{array}$ & $\begin{array}{l}\text { Yes, at least } \\
\text { once a month }\end{array}$ & $\begin{array}{l}\text { Yes, } \\
\text { occasionally }\end{array}$ & No & & \\
\hline 9 & 9 & 7 & 6 & 2 & & \\
\hline \multicolumn{7}{|c|}{ Principle 5 - Visual appeal } \\
\hline \multicolumn{7}{|c|}{ Do you post photos on your Facebook page? } \\
\hline $\begin{array}{l}\text { Yes, several } \\
\text { times a week }\end{array}$ & $\begin{array}{l}\text { Yes, at least } \\
\text { once a week }\end{array}$ & $\begin{array}{l}\text { Yes, at least } \\
\text { once a month }\end{array}$ & $\begin{array}{l}\text { Yes, } \\
\text { occasionally }\end{array}$ & No & & \\
\hline 8 & 14 & 4 & 5 & 4 & & \\
\hline \multicolumn{7}{|c|}{ Do you post videos on your Facebook page? } \\
\hline $\begin{array}{l}\text { Yes, several } \\
\text { times a week }\end{array}$ & $\begin{array}{l}\text { Yes, at least } \\
\text { once a week }\end{array}$ & $\begin{array}{l}\text { Yes, at least } \\
\text { once a month }\end{array}$ & $\begin{array}{l}\text { Yes, } \\
\text { occasionally }\end{array}$ & No & & \\
\hline 0 & 4 & 4 & 20 & 9 & & \\
\hline \multicolumn{7}{|c|}{ Principle 6-Community building and mobilisation } \\
\hline \multicolumn{7}{|c|}{$\begin{array}{l}\text { Do you post messages to thank your community and/or show your appreciation for the } \\
\text { support they provide to your organisation and to foster children? }\end{array}$} \\
\hline $\begin{array}{l}\text { Yes, } \\
\text { regularly }\end{array}$ & $\begin{array}{l}\text { Yes, } \\
\text { occasionally }\end{array}$ & Only rarely & No & & & \\
\hline 10 & 16 & 7 & 3 & & & \\
\hline \multicolumn{7}{|c|}{$\begin{array}{l}\text { Do you post comments about current issues or events that you think will interest your } \\
\text { Facebook community? }\end{array}$} \\
\hline $\begin{array}{l}\text { Yes, several } \\
\text { times a week }\end{array}$ & Yes, weekly & $\begin{array}{l}\text { Yes, at least } \\
\text { once a month }\end{array}$ & $\begin{array}{l}\text { Yes, } \\
\text { occasionally }\end{array}$ & No & & \\
\hline 8 & 8 & 10 & 9 & 2 & & \\
\hline \multicolumn{7}{|c|}{$\begin{array}{l}\text { Do you use posts or tabs on your Facebook page to (a) promote events (b) ask for } \\
\text { donations (c) seek volunteers }(d) \text { sell merchandise? }\end{array}$} \\
\hline $\begin{array}{l}\text { Promote } \\
\text { events }\end{array}$ & $\begin{array}{ll}\text { Ask for } \\
\text { donations }\end{array}$ & $\begin{array}{l}\text { Seek } \\
\text { volunteers }\end{array}$ & $\begin{array}{l}\text { Sell } \\
\text { merchandise }\end{array}$ & & & \\
\hline
\end{tabular}


1

2

3

4

5

6

7

8

9

\begin{tabular}{|l|l|l|l|l|l|l|}
\hline 33 & 0 & 6 & 0 & & & \\
\hline
\end{tabular}

Table 4 - Dialogic Outcome - Engagement

\begin{tabular}{|l|l|l|l|l|l|l|}
\hline How frequently do visitors post to your Timeline? \\
\hline $\begin{array}{l}\text { Daily or } \\
\text { more } \\
\text { frequently }\end{array}$ & $\begin{array}{l}\text { Two to three } \\
\text { times a week }\end{array}$ & One a week & $\begin{array}{l}2-3 \text { times a } \\
\text { month }\end{array}$ & $\begin{array}{l}\text { Less } \\
\text { frequently }\end{array}$ & Never & \\
\hline 7 & 6 & 4 & 6 & 11 & 4 & \\
\hline Do you have a Reviews tab on your profile and do you receive posts? & $\begin{array}{l}\text { Yes, but we } \\
\text { never receive } \\
\text { any posts }\end{array}$ & $\begin{array}{l}\text { Not have a do } \\
\text { reviews tab }\end{array}$ & \\
\hline $\begin{array}{l}\text { Yes, once a } \\
\text { week }\end{array}$ & $\begin{array}{l}\text { Yes, two to } \\
\text { three times a } \\
\text { month }\end{array}$ & $\begin{array}{l}\text { Yes, } \\
\text { occasionally }\end{array}$ & 0 & 5 & 21 & \\
\hline 1 & 0 & 0 &
\end{tabular}

Table 5 Dialogic Outcome - Network Extensiveness

\begin{tabular}{|l|l|l|l|l|l|l|l|}
\hline How many Likes do you currently have on your Facebook page? \\
\hline 0 to 499 & 500 to 999 & 1000 to 1999 & 2000 to 2999 & $\begin{array}{l}3000 \\
3999\end{array}$ & to & 4000 to 4999 & $5000+$ \\
\hline 11 & 7 & 2 & 3 & 1 & 2 & 2 \\
\hline How many & & & 3 & 1 & \\
\hline 0 to 9 & 10 to 24 & 25 to 49 & 50 to 99 & $100+$ & $\begin{array}{l}\text { We did you receive last month? } \\
\text { know }\end{array}$ & \\
\hline 7 & 11 & 6 & 4 & 4 & 2 & \\
\hline
\end{tabular}


Figure 1 Frequency distribution of the number of children in fostering care

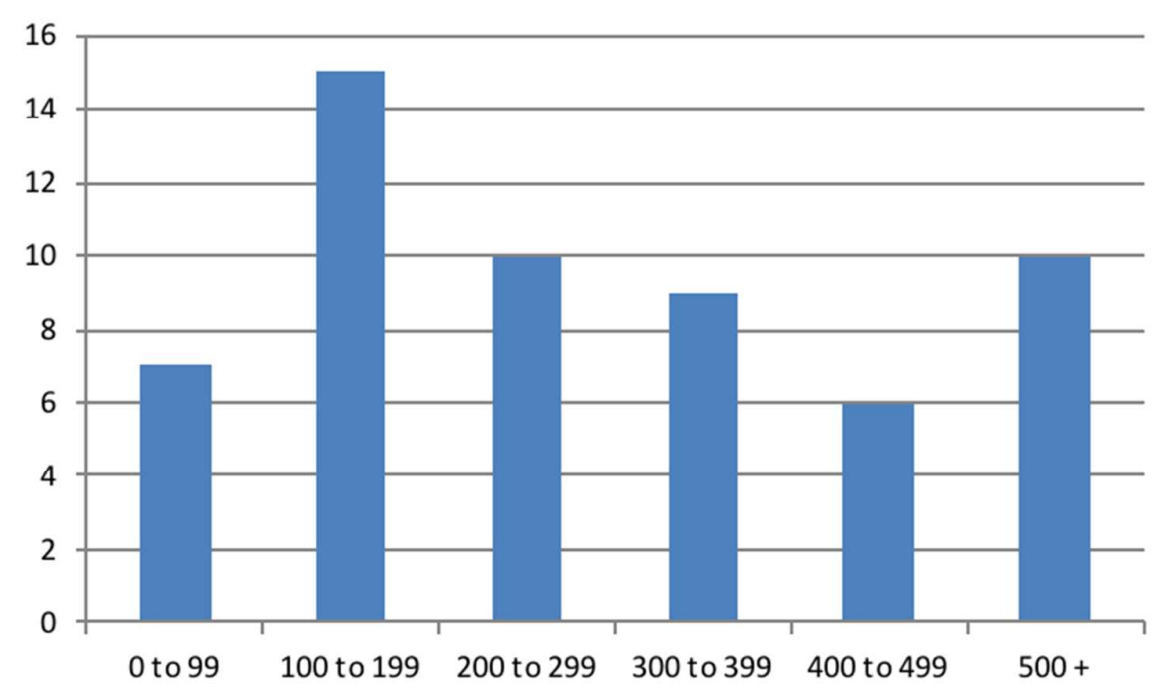

